\title{
ANTHROPOMETRIC STUDY OF VARIOUS ACETABULAR DIAMETERS IN THE HIP BONES OF NORTH INDIAN ORIGIN
}

\section{Anatomy}

Sanjay Gupta*

Associate professor, Department of Anatomy Pt. B. D. Sharma University of Health Sciences Rohtak. *Corresponding Author

Pratibha Dwivedi

Demonstrator, Department of Anatomy Pt. B. D. Sharma University of Health Sciences

Rohtak.

\section{Neeru Ghalawat}

Assistant professor, Department of Anatomy Pt. B. D. Sharma University of Health Sciences Rohtak.

\section{ABSTRACT}

Anatomy of hip bone is morphologically different in two ways due to different reproductive functions which are influenced by sex hormones. Therefore, shapes of hip bones are different in males and females that makes it interesting anthropologically and in surgical approaches. Though non-metric methods such as visual examination of bone morphologically for sex determination is entirely dependent on experience and expertise. But anthropometry plays a role in creating data which can be useful for sex determination in forensic sciences and in clinical application like in orthopedic implant size determination. Study material consisted of hip bone (female $=32$, males $=68$ ). The material was retrieved from the bone store of department of Anatomy, PGIMS Rohtak. Diameter of acetabulam was measured on these hip bones on both the sides and statistical analysis was done. The mean diameter of acetabulam in male was $41.29 \pm 3.06(\mathrm{R}), 41.22 \pm 3.09(\mathrm{~L}) \mathrm{mm}$ and female was $37.15 \pm 3.88(\mathrm{R}), 36.75 \pm 3.75(\mathrm{~L}) \mathrm{mm}$. The mean diameter of acetabulam on right was significantly greater in male than females.

\section{KEYWORDS}

\section{INTRODUCTION}

Hip bone or innominate bone is large irregular and shaped like a propeller, centrally constricted bone which is expanded above and below. Lateral surface of hip bone has acetabulum which is cup shaped, articulating with the femoral head. Antero-inferior to this is large obturator foramen, which is oval or triangular. Infront, pubic part of the bone bearing pubic tubercle and body articulates with its other side to form pelvic girdle

Hip bone usually displays differences in morphology independent of size due to different sexual and reproductive functions which are influenced by sex hormones. Therefore, morphology of hip bone and its differences in shape are different in males and females that make it interesting anatomically and anthropologically ${ }^{2}$. To determine the sex of an unknown individual is a challenging task in forensic investigations when human skeleton remains are found. Here pelvic bone has a role to play in determining the sex.

A hip bone is considered as ideal bone for sex determination as it provides the highest accuracy level for sex determination. Hence the hip bone is considered as the most reliable sex indicator in the human skeleton. Morphometric measurements done on the right and left sided hip bones indicate that there is bilateral asymmetry of hip bone ${ }^{3}$.

Subsequently researchers adopted osteometric methods to qualitatively differentiate between male and female hip bones

\section{MATERIALS \& METHODS}

The present study was conducted on 50 paired dry fully ossified human hip bones with known gender. The bones were collected from Department of Anatomy, Pandit Bhagwat Dayal Sharma University of Health Sciences, Rohtak, Haryana. Bones with gross damage or anomalies were excluded from the study. Digital Vernier Calliper was employed for accurate measurements.

Following morphometric measurements were documented in the present study:

1. The Horizontal diameter of the acetabulum- The maximum distance between the anterior and posterior ends of the acetabular cavity.

2. The vertical diameter of the acetabulum-The greatest distance between the upper and lower margins of the acetabular cavity.

3. The total acetabular diameter- The average of both the horizontal and vertical diameter

In our study, we took three readings of all above diameters and then took out mean of these three readings. Data analysis was carried out by SPSS software (version 20.0). The mean, standard deviation, range were calculated for all parameters. If $p$ - value was $<0.001$, then $\mathrm{P}$-value was considered as statistically significant.

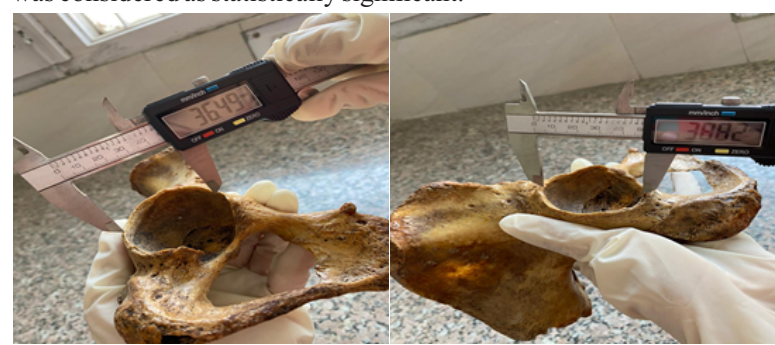

Fig 1: Measurement of

Maximum Horizontal Diameter (HD)
Fig 2: Measurement of

Maximum Vertical Diameter (VD)

\section{RESULTS:}

The present study was carried out on diameters of acetabular cavity, vertical and horizontal diameters of hip bones of both sides in both sexes.

Table: 1 Comparison of Total diameter, Vertical and Horizontal diameters of both side in male and female.

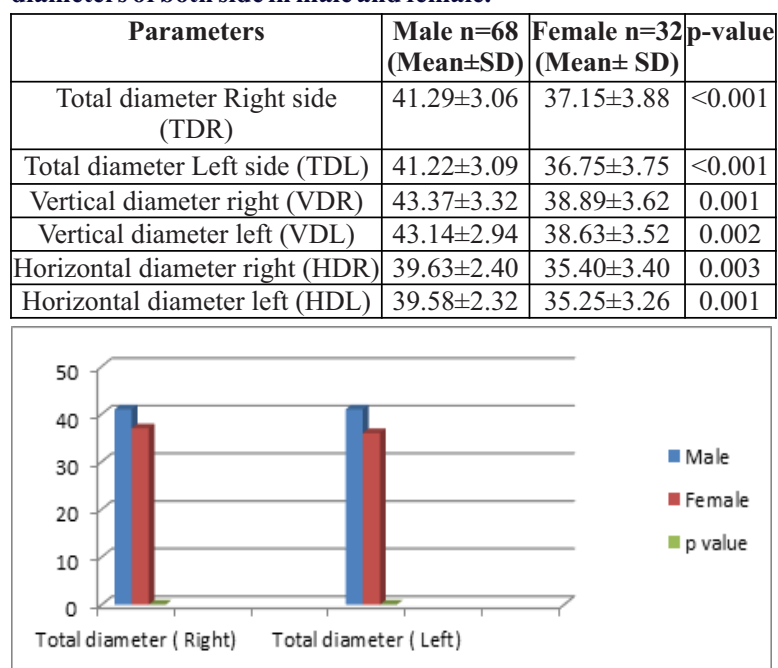

Graph 1. Showing total diameter on right and left side in male and female. 


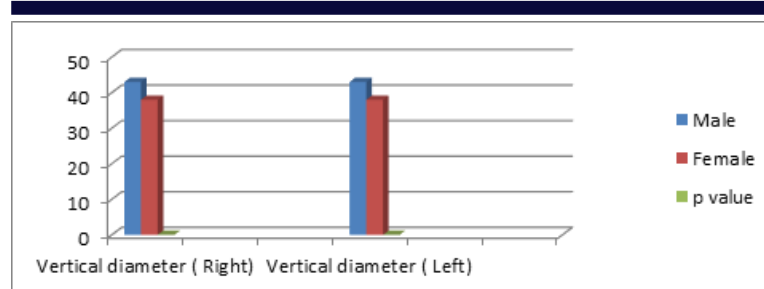

Graph 2: Showing vertical diameter of both side in male and female.

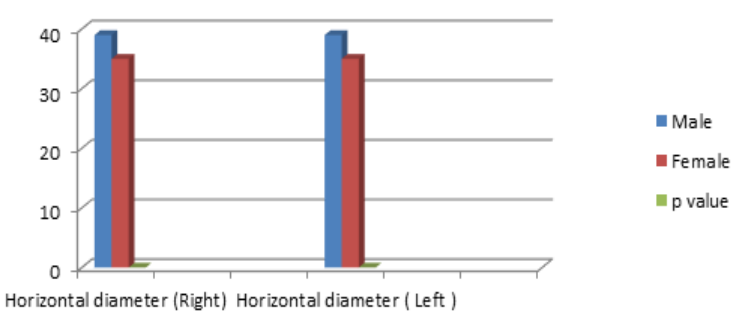

Graph 3: Showing Horizontal Diameter of both side in male and female.

Table:2 Comparison of Vertical and Horizontal diameters of both side hip bones.

\begin{tabular}{|c|c|c|c|c|}
\hline Parameters & $\begin{array}{c}\text { Left Total } \\
\text { Vertical } \\
\text { diameter }\end{array}$ & $\begin{array}{c}\text { Right Total } \\
\text { Vertical } \\
\text { diameter }\end{array}$ & $\begin{array}{c}\text { Total } \\
\text { Horizontal } \\
\text { diameter } \\
\text { (left) }\end{array}$ & $\begin{array}{c}\text { Total } \\
\text { Horizontal } \\
\text { diameter } \\
\text { (right) }\end{array}$ \\
\hline Mean \pm SD & $41.53 \pm 3.63$ & $41.56 \pm 3.55$ & $38.16 \pm 3.33$ & $38.37 \pm 3.48$ \\
\hline Range & $35.07-49.21$ & $33.44-49.96$ & $31.52-45.94$ & $32.02-46.85$ \\
\hline p-value & 0.9668 & 0.7585 & & \\
\hline
\end{tabular}

Table: 3 comparison of Total Mean Diameter of both sides.

\begin{tabular}{|c|c|c|c|}
\hline Parameters & Left side & Right side & p - value \\
\hline Total mean diameter & $39.85 \pm 3.86$ & $39.97 \pm 3.85$ & 0.619 \\
\hline
\end{tabular}

\section{DISCUSSION-}

Total hip replacement is a common surgery performed worldwide, so awareness of average dimension of the acetabulum is essential as it will help the prosthestist and surgeon to determine the correct size of the acetabular cup during total hip arthroplasty. In the present study, the total diameter, the vertical diameter and the horizontal diameter of both the sexes were compared with each other which shows that all the above diameters are significantly more in males.

On comparison, the values of acetabular diameters of both sides of same pelvis showed insignificant values.

On comparing the total acetabular diameters of present study with American, Chinese, South Indian the acetabular diameter is significantly less in present study. Also in South Indian studies in different sample size values did not change. But on comparing with other North Indian study done by Chauhan et al values in present study is still less. (Table 4)

On comparison of vertical diameters of right and left sides of pelvis with study done by Akhlaghi $\mathrm{M}$ et al on Iranian population vertical acetabular diameter of right side hip bone of female was more in North Indian region. (Table 5)

Table :4 Comparison of total acetabular diameter with the findings of previous studies.

\begin{tabular}{|c|c|c|c|c|c|}
\hline \multirow[t]{2}{*}{ Authors } & \multirow[t]{2}{*}{ Year } & \multirow[t]{2}{*}{ Population } & \multirow{2}{*}{$\begin{array}{c}\text { Sample } \\
\text { size }\end{array}$} & \multicolumn{2}{|c|}{ Diameter } \\
\hline & & & & Male & Female \\
\hline $\begin{array}{c}\text { Chauhan } \\
\text { et }^{5} l^{5}\end{array}$ & 2002 & North Indian & 48 & $\begin{array}{c}47.10 \pm 2.90 \\
\mathbb{R} \\
47.48 \pm 3.05 \\
(\mathrm{~L})\end{array}$ & \begin{tabular}{|c|}
$44.38 \pm 3.01(\mathrm{R})$ \\
$46.0 \pm 2.28$ \\
$(\mathrm{~L})$
\end{tabular} \\
\hline Krebs et $\mathrm{al}^{6}$ & 2009 & American & 100 & $53.7 \pm 3.74$ & $47.0 \pm 2.47$ \\
\hline Zeng et $\mathrm{al}^{7}$ & 2012 & Chinese & 200 & $\begin{array}{l}55.2 \pm 3.11(\mathrm{R}) \\
56.0 \pm 3.33(\mathrm{~L})\end{array}$ & \begin{tabular}{|c|}
$51.4 \pm 2.38$ \\
$(\mathrm{R})$ \\
$51.4 \pm 2.07(\mathrm{~L})$
\end{tabular} \\
\hline $\begin{array}{l}\text { Yugesh \& } \\
\text { kumar et al }\end{array}$ & 2016 & South Indian & 60 & $48.66 \pm 0.33$ & $46.18 \pm 0.24$ \\
\hline
\end{tabular}

\begin{tabular}{|c|c|c|c|c|c|}
\hline $\begin{array}{c}\text { Rajasekhar } \\
\text { et al }\end{array}$ & 2017 & South Indian & 206 & $48.1 \pm 3.1$ & $45.2 \pm 3.5$ \\
\hline $\begin{array}{c}\text { Present } \\
\text { study }\end{array}$ & 2020 & North Indian & 100 & $\begin{array}{l}41.29 \pm 3.06(\mathrm{R}) \\
41.22 \pm 3.09(\mathrm{~L})\end{array}$ & $\begin{array}{l}37.15 \pm 3.88(\mathrm{R}) \\
36.75 \pm 3.75(\mathrm{~L})\end{array}$ \\
\hline
\end{tabular}

Table: 5 Comparison of vertical and horizontal diameters of present study with findings of Akhlaghi $M$.

\begin{tabular}{|c|c|c|c|c|c|}
\hline \multirow[t]{2}{*}{\begin{tabular}{|l|} 
S. \\
No
\end{tabular}} & \multirow[t]{2}{*}{ Parameters } & \multicolumn{2}{|c|}{$\begin{array}{c}\text { Akhlaghi M et } \\
\operatorname{al}^{10}(2019) \text { Mean } \pm \text { SD }\end{array}$} & \multicolumn{2}{|c|}{$\begin{array}{l}\text { Present study } \\
\text { Mean } \pm \text { SD }\end{array}$} \\
\hline & & Male & Female & Male & Female \\
\hline \multirow[t]{2}{*}{1.} & $\begin{array}{c}\text { Vertical diameter } \\
\text { (right) }\end{array}$ & $47.0 \pm 4.0$ & $38.4 \pm 8.6$ & $43.37 \pm 3.32$ & $38.89 \pm 3.62$ \\
\hline & p-value & $<<0.0001$ & \multicolumn{3}{|c|}{0.001} \\
\hline \multirow[t]{2}{*}{2.} & $\begin{array}{c}\text { Vertical diameter } \\
\text { (left side) }\end{array}$ & $46.8 \pm 4.2$ & $40.6 \pm 2.5$ & $43.14 \pm 2.94$ & $38.63 \pm 3.52$ \\
\hline & $\mathrm{p}$-value & $<0.0001$ & \multicolumn{3}{|c|}{0.002} \\
\hline \multirow[t]{2}{*}{3.} & $\begin{array}{c}\text { Horizontal } \\
\text { diameter } \\
\text { (right side) }\end{array}$ & $49.2 \pm 3.9$ & $42.4 \pm 2.1$ & $39.63 \pm 2.4$ & $35.40 \pm 3.40$ \\
\hline & $p$-value & $<0.0001$ & \multicolumn{3}{|c|}{0.003} \\
\hline \multirow[t]{2}{*}{4.} & $\begin{array}{c}\text { Horizontal } \\
\text { diameter } \\
\text { (left side) }\end{array}$ & $48.8 \pm 4.3$ & $42.4 \pm 2.1$ & $39.58 \pm 2.32$ & $35.25 \pm 3.26$ \\
\hline & $\mathrm{p}$-value & \multicolumn{2}{|c|}{0.0001} & \multicolumn{2}{|c|}{0.001} \\
\hline
\end{tabular}

\section{CONCLUSION-}

There is significant difference in the size of acetabulum between present study and other studies and also sexual diamorphisim is also appreciated in present study. Therefore, significant data is obtained from this study which can be helpful to clinicians, orthopaedicians and forensic experts.

\section{REFERENCES-}

1. Mohammad MA, Mohammed J, Syeda AT. Sexual dimorphism of human hip bone with respect to chilotic index in north karnatka region. Int J of Sci St.2015; 3(6) .

Mohammed SMB, Tabhane MK, Ksheersagar DD. Sexual dimorphism in human hip Mohammed SMB, Tabhane MK, K

3. Kishan RS, Geetha KS. Pelvic bone indices as effective parameters of sex determination in skeleton remains: a cross sectional study. Int J of Res in Med Sci. 2014; 2(4): 15261529

4. Mukopadhya PP. Determination of sex by sciatic notch, acetabular ratio (Kelly's index in Indian Bengali skeletal remains. J Ind Acad for Med. 2012;34(1).

5. Chauhan R, Paul S, Dhaon BK. Anatomical parameters of North Indian hip jointscadaveric study. J Anat Soc India 2002; 51:39-42.

6. Krebs, V.; Incavo, S. J. \& Shields, W. H. The anatomy of the acetabulum: what is normal? Clin. Orthop. Relat. Res., 467(4):868-75,2009

7. Zeng, Y, Wang, Y, Zhu, Z, Tang, T, Dai K. \& Qiu S. Differences in acetabula morphology related to side and sex in a Chinese population. J. Anat., 220(3):256-62, 2012

8. Yugesh and Senthil KS. Morphometric analysis of acetabulum and its clinical correlation in south Indian population. IJAR. 2016;2(6):1011-14.

9. Rajasekhar S, Vasudha TK \& Aravindhan K. Sex Determination by biometry of anterio features of human hip bones in South Indian population. J. Clin. Diagn. Res. 11(6):AC13-AC16, 2017.

10. Akhlaghi M, Azizian A, Sadeghian MH, Forghani T, Tavakoli SAH, Rafiee Sh, et al. Comparing the Accuracy of Morphometric and Morphological Criteria of Hip Bone in Gender Determination. International Journal of Medical Toxicology and Forensic Medicine. 2019;9(2):57-64 